\title{
Efficiency and Effectiveness of Government Expenditure on Education at Districts/Cities Level in East Java Indonesia
}

\author{
Achmad Solihin $^{1}$, Djoko Mursinto ${ }^{1} \&$ Lilik Sugiharti $^{1}$ \\ ${ }^{1}$ Faculty of Economics and Business, Universitas Airlangga, Indonesia \\ Correspondence: Achmad Solihin, Faculty of Economics and Business, Universitas Airlangga, Indonesia. Tel: \\ 62-81-132-2650. E-mail: kinsola@yahoo.com
}

Received: May 3, 2017

doi:10.5539/ass.v13n8p91
Accepted: May 26, $2017 \quad$ Online Published: July 25, 2017

URL: https://doi.org/10.5539/ass.v13n8p91

\begin{abstract}
The purpose of this study is to investigate and analyze the efficiency and effectiveness of local government expenditure on education sector in districts and cities level of East Java, during the periods 2007-2014. Furthermore, this study will evaluate the impacts of local government expenditure, household expenditure for education, and regional product domestic bruto or (PDRB) on the educational outcomes, namely education index.

Data Envelopment Analysis (DEA) is selected as the methodology for analyzing the efficiency of local government expenditure on educational outcome. The model assumes constant return to scale (CRS) and variable return to scale (VRS). Measurement of the effectiveness of government spending is done by using panel data regression. Data for supporting the analyses is panel data from 38 districts and cities in East Java for the periods of 2007 - 2014. The results show that government expenditure in educational sector is relatively inefficient. Government Expenditure for Education (PPP) has no significant impact on educational index, while Household expenditure for education (PPRT) and GRDP per Capita positive has significant impact on the Education Index (IP). This imply that government expenditure for educational sector is not effective improving educational index.
\end{abstract}

Keywords: DEA, Effectiveness, Efficiency, Government Expenditure on Education

\section{Introduction}

The regional development processes is strongly associated with local government commitment in terms of determining strategic sectors to be pushed as the leading sector. The choices of development priority might vary among regions, because it depends on the region's potential and situation. The economic consequence of choice for regional development priority is resources allocation to support the program. The resource or budget allocation of local government will be directly for supporting the selected and strategic sector.

The larger budget share allocated for the selected sector, the higher the probability the selected sector can achieve the target efficiently. The argument is because larger share of budget means more programs can be implemented to support all the development targets. It is regulated by the Law number 20/2003 which regulated educational system in Indonesia. This Law specifically give mandate that both local and central government have to allocate budget for supporting educational development, with the minimum share of 20 percent.

East Java is one of the provinces that has development priority in educational sector. Even though education and human capital development are the priority of regional development, there are some problems left behind. There is no linier progress between budget share and targeted educational outcome in East Java. One of the targeted outcome is an improvement in Human Development Index (HDI) of East Java province. Low HDI index relate with low quality of educational outcome among 38 districts and cities in this province.

Educational indicators achievement in 38 Districts in East Java Province very diverse. Some regions have high enough education indicator achievements while some regions are left behind. Some districts allocate high share of education budget, but these regions not able to improve the education sector indicator achievements compare to other areas which have lower spending.

The human development indicators are not evenly achieved among the regions. The indicator also not linier with the share of budget sending among various sctors. Scale of budget spending for education varies among districts 
and city in East Java. According to Prasetyo and Ubaidallahi (2013) many empirical studies report the impact of government spending on specific indicators achievements. Suescún (2007) states that the expenditure of the government infrastructure sector has a more significant impact than other sector expenditure, namely education and health; have positive impact on the achievement of human development indicators in Latin American countries. Furthermore, Prasetyo and Ubaidallahi (2013) state that this variation appears due to the level of the efficiency of government spending among countries.

Unbalances between budget allocation and development target, performance level in educational level in East Java province give strong motivation for author for exploring the impact of educational spending and it outcome. The purpose of this study is to investigate and analyzing the effectiveness of local government expenditure on education sector among various districts and cities of East Java Indonesia between 2007-2014 periods. Furthermore, this study will evaluate the according of local government expenditure, household expenditure for education, and regional gross domestic product or PDRB on the educational outcomes, namely education index.

\section{Method}

\subsection{The effeciency of the expenditure of the Government in the field of education}

The DEA is conducted as method to calculate efficiency in this research which using a CRS model as can be seen in the equations below. To estimate efficiency in educational sectors, the following equations will be estimated.

$$
\max e_{0}=\mu_{1} R G M+\mu_{2} R K M+\mu_{3} R S P
$$

Subject to:

$$
\begin{aligned}
& V_{1} P P=1 \\
& \mu_{1} R G M_{i}+\mu_{2} R K M_{i}+\mu_{3} R S P_{i}-V_{1} P P_{i} \leq 0 \\
& \mu_{1,2,3}, v_{1} \geq 0
\end{aligned}
$$

The Model of Variable Return to Scale (VRS) in accordance with the similarities and equation 2.1 to 2.4 are as follows :

$$
\max e_{0}=\mu_{1} R G M+\mu_{2} R K M+\mu_{3} R S P+\mu_{0}
$$

Subject to:

$$
\begin{aligned}
& V_{1} P P=1 \\
& \mu_{1} R G M_{i}+\mu_{2} R K M_{i}+\mu_{3} R S P_{i}-V_{1} P P_{i} \leq 0 \\
& \mu_{1,2,3}, v_{1} \geq 0
\end{aligned}
$$

Description: $\quad \mathrm{RGM} \quad=$ The ratio or the number of teachers per student

$$
\begin{array}{ll}
\mathrm{RKM} & =\text { The ratio or the number of classrooms per student } \\
\mathrm{RSP} & =\text { The ratio or the number of schools per school-age population }
\end{array}
$$$$
\text { PP } \quad=\text { level of government spending }
$$

$\mu_{1,2,3}=$ the weight for the output RGM, RKM, RSP

$\mathrm{V} 1=$ the weight of input $\mathrm{PP}$

$\mu_{O} \quad=$ coefficient that can be valuable positive or negative

$\mathrm{i} \quad=$ individual unit (district)

\subsection{The effectiveness of the expenditure of the Government in the field of education}

The effectiveness of government spending in the education sector is measured with how to perform multiple 
regression from the input variable and socio economic variables to the outcome variables which in this case is defined as index of education. Panel regression technique is used as main analysis. Wooldridge (2012) descibes that endogenity problems can arise because of two things. First, the omitted variable, i.e. exempting important variables in the model; and second, simultaneity that occurs when independent variables (x) and one of the group of dependent variables (y) influenced by one or groups of external variable in the model.

Theoretically expenditures will not have impact on the same year the index of education but it will affect minimal one year after the spending is allocated. The measurement or estimation of the effectiveness of government spending in the education sector started with the panel data regression on the input variables and outcome. The regression model used for education regression is as follows.

$$
Y_{p i t}=\alpha_{0}+\alpha_{1} P P P_{i t-1}+\alpha_{2} P P R T_{i t-1}+\alpha_{3} \ln P D R B_{i t-1}+\mu_{i t}
$$

Description:

$$
\begin{aligned}
& Y_{p i t} \quad=\text { education index } \\
& P P P_{i t-1} \quad=\text { the ratio of the government spending for the education sector toward total expenditures. } \\
& P P R T_{i t-1}=\text { the ratio of the household spending for the education of the total household spending. } \\
& \begin{array}{ll}
\ln P D R B_{i t-1} & =\text { distric natural Regional GDP per capita } \\
i \quad & =\text { district in East Java } \\
t \quad & =\text { years }(2007, \ldots, 2014) \\
\mu & =\text { error term }
\end{array}
\end{aligned}
$$

There are several stages in the regression using panel data. First, the determination of the best estimate model; second, classical assumption testing; and third, partial significance and simultaneous testing. On the analysis of the panel data model, are known for three kinds of estimation approach that offered the least square (pooled least square), panel fixed effect and random effects approach.

\section{Results}

\subsection{Technical Analysis of the cost of assuming Constant Return to scale installation design (CRS)}

Analysis of the technical efficiency is cost analysis that measure efficiency levels between the input variable for variable output with the input approach orientation. The value of the cost of the technical efficiency is used to evaluate the extent of the efficiency of input use in the form of realization of the expenditure of the government education issued each district government/city in East Java Province. Efficient government spending prioritizes to produce public services and facilities in the field of education to the community. In the first part of the analysis of the technical efficiency the cost of using the assumption of the constant return to scale installation design (CRS).

Table 1 shows the value of efficiency in 38 districts of the province of East Java year 2007-2014 assuming CRS. There is no districts or cities for the periods eight years (2007-2014) that can successfully achieved the condition of efficient efficiency=1). Government spending produce public services in the field of education, but there are four areas that almost very efficient every year, namely Sidoarjo Regency, Mojokerto City, Pasuruan City, and the Blitar City.

Table 1. The efficiency scores based on DEA results with CRS assumption

\begin{tabular}{llllllllll}
\hline No. & Districts & 2007 & 2008 & 2009 & 2010 & 2011 & 2012 & 2013 & 2014 \\
\hline 1 & Pacitan & 0.670 & 0.761 & 0.798 & 0.453 & 0.692 & 0.718 & 0.613 & 0.738 \\
2 & Ponorogo & 0.739 & 0.703 & 0.644 & 0.462 & 0.682 & 0.807 & 0.565 & 0.787 \\
3 & Trenggalek & 0.823 & 0.702 & 0.665 & 0.540 & 0.713 & 0.868 & 0.658 & 0.805 \\
4 & Tulungagung & 0.856 & 0.635 & 0.673 & 0.534 & 0.788 & 0.932 & 0.694 & 0.892 \\
5 & Blitar & 0.913 & 0.706 & 0.694 & 0.562 & 0.791 & 1.000 & 0.653 & 0.844 \\
6 & Kediri & 0.963 & 0.833 & 0.793 & 0.706 & 0.967 & 0.931 & 0.755 & 0.836 \\
7 & Lumajang & 0.804 & 0.730 & 0.730 & 0.670 & 0.842 & 0.887 & 0.720 & 0.782 \\
8 & Malang & 1.000 & 0.712 & 0.727 & 0.618 & 0.631 & 0.783 & 0.653 & 0.700 \\
9 & Jember & 0.865 & 0.696 & 0.713 & 0.673 & 0.845 & 1.000 & 0.707 & 0.802 \\
10 & Banyuwangi & 0.826 & 0.674 & 0.66 & 0.749 & 0.666 & 0.770 & 0.646 & 0.724 \\
11 & Bondowoso & 0.656 & 0.53 & 0.514 & 0.577 & 0.551 & 0.691 & 0.638 & 0.735 \\
\hline
\end{tabular}




\begin{tabular}{|c|c|c|c|c|c|c|c|c|c|}
\hline 12 & Situbondo & 0.875 & 0.606 & 0.615 & 0.736 & 0.871 & 1.000 & 0.733 & 0.853 \\
\hline 13 & Probolinggo & 0.647 & 0.545 & 0.501 & 0.440 & 0.66 & 0.836 & 0.711 & 0.692 \\
\hline 14 & Pasuruan & 0.884 & 0.647 & 0.633 & 0.800 & 0.698 & 0.937 & 0.754 & 0.812 \\
\hline 15 & Sidoarjo & 1.000 & 1.000 & 0.905 & 0.975 & 1.000 & 1.000 & 1.000 & 1.000 \\
\hline 16 & Mojokerto & 0.756 & 0.635 & 0.635 & 1.000 & 0.989 & 1.000 & 0.656 & 0.897 \\
\hline 17 & Jombang & 0.748 & 0.648 & 0.62 & 0.572 & 0.672 & 0.813 & 0.719 & 0.765 \\
\hline 18 & Nganjuk & 0.664 & 0.619 & 0.582 & 0.942 & 0.658 & 0.737 & 0.618 & 0.725 \\
\hline 19 & Madiun & 0.887 & 0.776 & 0.747 & 0.643 & 0.765 & 0.916 & 0.778 & 1.000 \\
\hline 20 & Magetan & 0.768 & 0.708 & 0.743 & 0.498 & 0.681 & 0.907 & 0.543 & 0.743 \\
\hline 21 & Ngawi & 1.000 & 0.883 & 0.837 & 0.462 & 0.644 & 0.621 & 0.505 & 0.796 \\
\hline 22 & Bojonegoro & 0.856 & 0.682 & 0.682 & 0.390 & 0.597 & 0.813 & 0.609 & 0.782 \\
\hline 23 & Tuban & 0.892 & 0.717 & 0.659 & 0.841 & 0.705 & 0.895 & 0.624 & 0.859 \\
\hline 24 & Lamongan & 0.769 & 0.617 & 0.599 & 0.551 & 0.686 & 0.820 & 0.675 & 0.795 \\
\hline 25 & Gresik & 0.818 & 0.701 & 0.658 & 0.766 & 0.772 & 0.912 & 0.821 & 0.813 \\
\hline 26 & Bangkalan & 0.938 & 0.686 & 0.653 & 0.611 & 0.560 & 0.633 & 1.000 & 1.000 \\
\hline 27 & Sampang & 0.755 & 0.586 & 0.608 & 0.560 & 0.534 & 0.742 & 0.774 & 0.632 \\
\hline 28 & Pamekasan & 1.000 & 0.658 & 0.625 & 0.600 & 0.714 & 0.840 & 0.757 & 0.759 \\
\hline 29 & Sumenep & 0.676 & 0.558 & 0.526 & 0.444 & 0.606 & 0.726 & 0.543 & 0.726 \\
\hline 30 & Kediri City & 0.997 & 0.888 & 0.937 & 0.905 & 0.899 & 1.000 & 0.965 & 1.000 \\
\hline 31 & Blitar City & 1.000 & 1.000 & 1.000 & 1.000 & 1.000 & 0.993 & 1.000 & 1.000 \\
\hline 32 & Malang City & 0.724 & 0.813 & 0.711 & 0.637 & 0.742 & 0.785 & 0.765 & 0.675 \\
\hline 33 & Probolinggo City & 0.362 & 0.329 & 0.322 & 0.362 & 0.353 & 0.371 & 0.362 & 0.360 \\
\hline 34 & Pasuruan City & 1.000 & 0.991 & 0.958 & 0.957 & 1.000 & 1.000 & 1.000 & 1.000 \\
\hline 35 & Mojokerto City & 1.000 & 1.000 & 1.000 & 1.000 & 1.000 & 1.000 & 1.000 & 0.928 \\
\hline 36 & Madiun City & 0.844 & 0.919 & 0.919 & 0.899 & 0.805 & 0.946 & 0.920 & 0.781 \\
\hline 37 & Surabaya City & 0.682 & 0.622 & 0.582 & 0.718 & 0.845 & 0.662 & 0.665 & 0.677 \\
\hline \multirow[t]{2}{*}{38} & Batu City & 0.704 & 0.682 & 0.735 & 0.694 & 0.605 & 0.775 & 0.713 & 0.674 \\
\hline & Average & 0.825 & 0.716 & 0.700 & 0.672 & 0.743 & 0.844 & 0.724 & 0.800 \\
\hline
\end{tabular}

3.2 Technical cost efficiency analysis with the assumption of Variable Return to scale installation design (VRS)

This section will discuss the technical cost analysis with VRS assumption. Results of VRS assumption will be analyzed in five districts or areas which experience efficience condition in terms of government expenditure allocation for education input to produce public services and facilities in education (the output) in its territory in eight years. These regency are: Situbondo, Pamekasan, Sumenep, and the Blitar City and Kediri City. The nine areas which are also efficient almost every year, namely Malang city, Mojokerto, Pasuruan, Sampang Regency, Lamongan, Gresik, Magetan, Madiun, and Sidoarjo. Compared with using assumptions CRS, assuming VRS can produce more efficient areas in eight years of research.

Table 2. The efficiency Scores of the DEA Analysis with VRS Assumptions

\begin{tabular}{llllllllll}
\hline No. & Districts & 2007 & 2008 & 2009 & 2010 & 2011 & 2012 & 2013 & 2014 \\
\hline 1 & Pacitan & 0.782 & 1.000 & 1.000 & 0.455 & 0.840 & 1.000 & 0.897 & 1.000 \\
2 & Ponorogo & 0.875 & 0.901 & 0.826 & 0.480 & 0.844 & 0.927 & 1.000 & 1.000 \\
3 & Trenggalek & 0.892 & 0.859 & 0.812 & 0.544 & 1.000 & 0.945 & 0.807 & 0.874 \\
4 & Tulungagung & 0.929 & 0.708 & 0.754 & 0.572 & 0.87 & 0.932 & 0.81 & 0.964 \\
5 & Blitar & 1.000 & 0.900 & 0.864 & 0.566 & 0.974 & 1.000 & 0.833 & 0.914 \\
6 & Kediri & 1.000 & 0.915 & 0.872 & 0.722 & 1.000 & 0.982 & 0.762 & 0.836 \\
7 & Lumajang & 0.839 & 0.783 & 0.766 & 0.703 & 0.974 & 0.947 & 0.818 & 0.783 \\
8 & Malang & 1.000 & 1.000 & 1.000 & 0.620 & 0.660 & 0.850 & 0.665 & 0.701 \\
9 & Jember & 0.925 & 0.757 & 0.767 & 0.681 & 0.852 & 1.000 & 0.829 & 0.802 \\
10 & Banyuwangi & 0.831 & 0.685 & 0.675 & 0.763 & 0.677 & 0.771 & 0.687 & 0.729 \\
11 & Bondowoso & 1.000 & 0.678 & 0.639 & 0.876 & 0.624 & 0.794 & 0.745 & 0.892 \\
12 & Situbondo & 1.000 & 1.000 & 1.000 & 1.000 & 1.000 & 1.000 & 1.000 & 1.000 \\
13 & Probolinggo & 1.000 & 0.639 & 0.585 & 0.440 & 1.000 & 1.000 & 1.000 & 0.911 \\
\hline
\end{tabular}




\begin{tabular}{|c|c|c|c|c|c|c|c|c|c|}
\hline 14 & Pasuruan & 0.940 & 0.657 & 0.646 & 0.927 & 0.700 & 0.956 & 0.888 & 0.812 \\
\hline 15 & Sidoarjo & 1.000 & 1.000 & 0.942 & 1.000 & 1.000 & 1.000 & 1.000 & 1.000 \\
\hline 16 & Mojokerto & 0.804 & 0.668 & 0.662 & 1.000 & 1.000 & 1.000 & 0.716 & 0.934 \\
\hline 17 & Jombang & 0.935 & 0.656 & 0.627 & 0.580 & 0.741 & 0.873 & 0.838 & 0.775 \\
\hline 18 & Nganjuk & 0.697 & 0.637 & 0.600 & 1.000 & 0.732 & 0.769 & 0.668 & 0.736 \\
\hline 19 & Madiun & 1.000 & 1.000 & 1.000 & 0.643 & 1.000 & 0.977 & 1.000 & 1.000 \\
\hline 20 & Magetan & 1.000 & 1.000 & 1.000 & 0.516 & 1.000 & 1.000 & 1.000 & 0.844 \\
\hline 21 & Ngawi & 1.000 & 1.000 & 1.000 & 0.506 & 0.931 & 0.642 & 0.648 & 0.854 \\
\hline 22 & Bojonegoro & 0.961 & 0.801 & 0.811 & 0.465 & 0.709 & 0.952 & 0.783 & 0.891 \\
\hline 23 & Tuban & 0.962 & 0.748 & 0.701 & 1.000 & 0.783 & 0.966 & 0.719 & 0.900 \\
\hline 24 & Lamongan & 1.000 & 0.906 & 0.875 & 1.000 & 1.000 & 1.000 & 1.000 & 1.000 \\
\hline 25 & Gresik & 1.000 & 0.835 & 0.765 & 1.000 & 1.000 & 1.000 & 1.000 & 0.814 \\
\hline 26 & Bangkalan & 1.000 & 0.732 & 0.697 & 0.648 & 0.560 & 0.637 & 1.000 & 1.000 \\
\hline 27 & Sampang & 1.000 & 1.000 & 1.000 & 0.847 & 0.657 & 0.980 & 1.000 & 1.000 \\
\hline 28 & Pamekasan & 1.000 & 1.000 & 1.000 & 1.000 & 1.000 & 1.000 & 1.000 & 1.000 \\
\hline 29 & Sumenep & 1.000 & 1.000 & 1.000 & 1.000 & 1.000 & 1.000 & 1.000 & 1.000 \\
\hline 30 & Kediri City & 1.000 & 1.000 & 1.000 & 1.000 & 1.000 & 1.000 & 1.000 & 1.000 \\
\hline 31 & Blitar City & 1.000 & 1.000 & 1.000 & 1.000 & 1.000 & 1.000 & 1.000 & 1.000 \\
\hline 32 & Malang city & 1.000 & 1.000 & 1.000 & 0.662 & 1.000 & 0.835 & 1.000 & 0.772 \\
\hline 33 & Probolinggo city & 0.398 & 1.000 & 1.000 & 1.000 & 1.000 & 0.426 & 0.411 & 0.386 \\
\hline 34 & Pasuruan City & 1.000 & 0.991 & 0.958 & 0.993 & 1.000 & 1.000 & 1.000 & 1.000 \\
\hline 35 & Mojokerto city & 1.000 & 1.000 & 1.000 & 1.000 & 1.000 & 1.000 & 1.000 & 0.995 \\
\hline 36 & Madiun City & 0.856 & 0.963 & 0.948 & 0.908 & 0.813 & 0.964 & 1.000 & 0.814 \\
\hline 37 & Surabaya city & 0.683 & 0.654 & 0.611 & 0.767 & 1.000 & 0.667 & 0.665 & 0.683 \\
\hline \multirow[t]{2}{*}{38} & Batu city & 1.000 & 0.700 & 0.747 & 0.695 & 0.628 & 0.775 & 0.821 & 0.682 \\
\hline & Average & 0.929 & 0.862 & 0.846 & 0.778 & 0.883 & 0.910 & 0.869 & 0.876 \\
\hline
\end{tabular}

\subsection{The effectiveness of Government Spending on Education Sector}

This study find that government spending on education sector, household spending for education and Regional GDP per capita is not directly affects in the same time to the index of education. Therefore, this study will elaborate data processing using one year time lag for the three independent variables. The result of the estimation is shown in Table 3.

Regression results using this method pooled square (PLS), Fixed Effect (FEM), and Random Effect (REM) is as follows.

Table 3. The Result of Panel Data Regression Estimation Lag 1 Based on Three Estimation Methods

\begin{tabular}{|c|c|c|c|c|}
\hline \multirow{2}{*}{\multicolumn{2}{|c|}{ The variables }} & \multicolumn{3}{|c|}{ Estimation of Model } \\
\hline & & PLS & FEM & REM \\
\hline \multirow{4}{*}{ PPP } & coefficient & $-3,973167$ & 0,8604255 & 0,8108955 \\
\hline & Std. error & 5,906605 & 1,171732 & 1,202401 \\
\hline & T-statistics & $-0,67$ & 0.73 & 0.67 \\
\hline & Prob. & 0,502 & 0,464 & 0,500 \\
\hline \multirow{4}{*}{ PPRT } & coefficient & 24,03819 & 1,032646 & 1,23403 \\
\hline & Std. error & 2,570518 & 0,6034629 & 0,6150796 \\
\hline & T-statistics & 9.35 & 1.71 & 2.01 \\
\hline & Prob. & 0,000 & 0,088 & 0,045 \\
\hline \multirow{4}{*}{ LnPDRB } & coefficient & 5,151463 & 7,355819 & 7,395031 \\
\hline & Std. error & 0,6654689 & 0,3794257 & 0,3754699 \\
\hline & T-statistics & 7,74 & 19,39 & 19,70 \\
\hline & Prob. & 0,000 & 0,000 & 0,000 \\
\hline \multicolumn{2}{|c|}{$R$-squared $\left(\mathrm{R}^{2}\right)$} & 0,5322 & 0,6341 & 0,3920 \\
\hline \multicolumn{2}{|c|}{ Prob. (F-stat) } & 0,0000 & 0,0000 & 0,0000 \\
\hline
\end{tabular}


The Lagrange Multiplier test or LM-test used to determine whether the model of random effect model (REM) or PLS model that is more suitable for use in mengestimasi panel data. The hypothesis of zero on the LM test is varians all entity is equal to zero, or in other words choose the model PLS.

LM tests is evaluated by comparing the value of LM statistics with the count value of chi square, or it can also be made by comparing the value of probability ( $p$-value) chi-square with the alpha value. The value of probability ( $p$-value) chi-square is 0,0000 less than the value of the alpha $(0.05)$. Thus the decision to be taken is rejecting $\mathrm{H}_{0}$, namely selecting random effect model (REM).

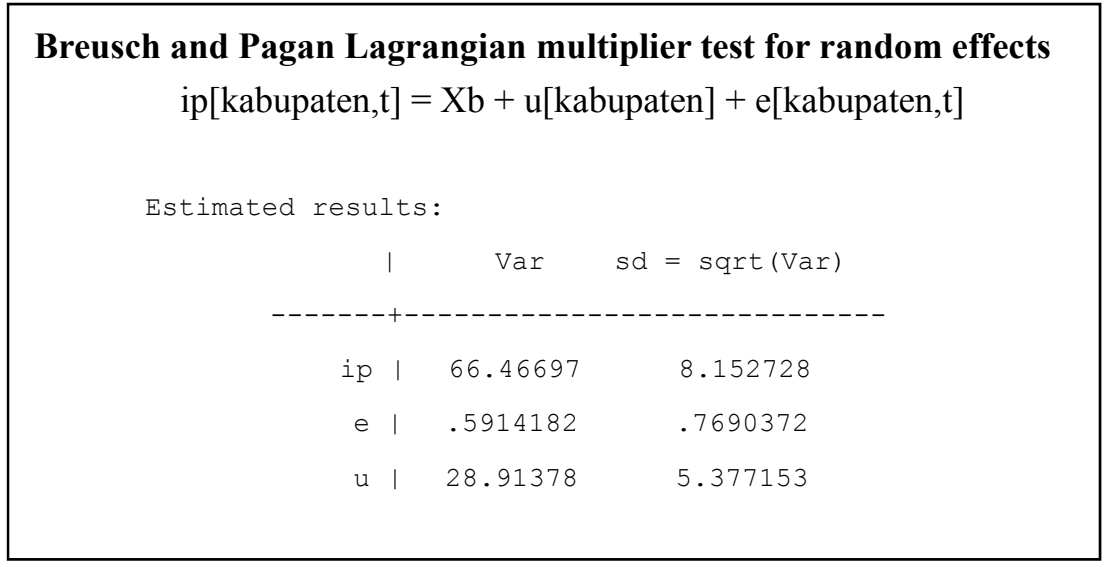

Test results of LM test shows that the decision taken in Hausman test is used to see the consistency of OLS estimation. This test is also used to know whether the model of random effect or model fixed effect to better estimate panel data model. The null hypothesis on the Hausman test is an interruption between the individual (select random effect), while hypothesis one is that there is no difference between the individual (select fixed effect).

Hausman tests is done by comparing the value of Hausman statistics and the value of Chi-Square. The test also can be done by comparing the value of probability ( $p$-value) with the alpha value. The result of the estimation shows that the probability is 0,9035 ; which value is more than alpha $(0.05)$.The decision is receiving null hypothesis $\left(\mathrm{H}_{0}\right)$, namely selecting REM model.

Based on the testing of the significance level (partially), which is obtained from the coefficient on each independent variable has a different value. The identification of each of the variables described as follows:

a. Regression coefficient for ratio of the government spending in the education sector toward total expenditures (PPP) is 0.8108 with probability 0.500 . This means that the hypothesis null $\left(\mathrm{H}_{0}\right)$ is accepted, so that the ratio of the government spending in the education sector toward total expenditures (PPP) from the previous year partially does not have a significant impact on education index (IP).

b. Regression coefficient for ratio of household spending for the education of the total expenditures is 1.2340 with 0.045 ; this probability is significant on the level of $\alpha=5$ percent. This means that the $\mathrm{H}_{0}$ rejected and $\mathrm{H}_{1}$ accepted, so that the variables partially have a significant impact on education index (IP). The value of the coefficient shows the positive relationship between the two variables, namely if the ratio of household spending for education per total expenditures of the previous year increased by 1 percent, then the index will increase by 1.2340 education with the assumption of the other variables remain.

c. The growth regression for coefficient regional gross domestic product per capita or logarithm value of PDRB is 7.3950 with 0.000 probability that significant on the level of $\alpha=5$ percent. This means that the $\mathrm{H}_{0}$ rejected and $\mathrm{H}_{1}$ accepted, so that the variables partially have a significant impact on education index (IP). The value of the coefficient shows the positive relationship between the two variables, namely if the value of the growth of regional gross domestic product per capita one of the previous year increased by 1 percent, education index will rise by 7.3950 percent with other variables considered constant assumptions.

\section{Discussions}

\subsection{The efficiency of the Education Sector with the assumption of the CRS}

Constant Return to scale installation design (CRS) assumes that each DMU will operate at a constant return scale where the same proportional changes in the input level will produce the same proportional change in output 
levels, so that the addition of production factor input will not have an impact on the addition or reduction of output (output) and productivity that may be achieved. Another assumption used in the CRS is DMU is operating in optimal scale, so that the scale of production does not affect the efficiency.

Table 4. The Change of Efficiency Scores in Several Regions across Years with CRS Assumptions

\begin{tabular}{lllllllll}
\hline Municipal & 2007 & 2008 & 2009 & 2010 & 2011 & 2012 & 2013 & 2014 \\
\hline Mojokerto city & 1.000 & 1.000 & 1.000 & 1.000 & 1.000 & 1.000 & 1.000 & 0.928 \\
Blitar city & 1.000 & 1.000 & 1.000 & 1.000 & 1.000 & 0.993 & 1.000 & 1.000 \\
Sidoarjo & 1.000 & 1.000 & 0.905 & 0.975 & 1.000 & 1.000 & 1.000 & 1.000 \\
Pasuruan City & 1.000 & 0.991 & 0.958 & 0.957 & 1.000 & 1.000 & 1.000 & 1.000 \\
Kediri City & 0.997 & 0.888 & 0.937 & 0.905 & 0.899 & 1.000 & 0.965 & 1.000 \\
Mojokerto & 0.756 & 0.635 & 0.635 & 1.000 & 0.989 & 1.000 & 0.656 & 0.897 \\
Bangkalan & 0.938 & 0.686 & 0.653 & 0.611 & 0.560 & 0.633 & 1.000 & 1.000 \\
Madiun & 0.887 & 0.776 & 0.747 & 0.643 & 0.765 & 0.916 & 0.778 & 1.000 \\
Blitar & 0.913 & 0.706 & 0.694 & 0.562 & 0.791 & 1.000 & 0.653 & 0.844 \\
Malang & 1.000 & 0.712 & 0.727 & 0.618 & 0.631 & 0.783 & 0.653 & 0.700 \\
Jember & 0.865 & 0.696 & 0.713 & 0.673 & 0.845 & 1.000 & 0.707 & 0.802 \\
Situbondo & 0.875 & 0.606 & 0.615 & 0.736 & 0.871 & 1.000 & 0.733 & 0.853 \\
Ngawi & 1.000 & 0.883 & 0.837 & 0.462 & 0.644 & 0.621 & 0.505 & 0.796 \\
Pamekasan & 1.000 & 0.658 & 0.625 & 0.600 & 0.714 & 0.840 & 0.757 & 0.759 \\
\hline
\end{tabular}

Table 4 shows the efficient areas in the education sector the year 2007-2014. The result of the analysis of DEA with CRS assumption shows that there is no consistent area always efficient from the year 2007-2014. The city of Mojokerto always efficient from the year 2007-2013, while in the year 2014 become inefisien with the value of the efficiency to 0,928. The city of Blitar always efficient in years 2007-2011, then become inefisien in 2012 with the value of the efficiency of a 0,993; and in the year 2013-2014 increased again become more efficient. Sidoarjo Regency efficient in the year 2007-2008, then become inefisien in 2009 and 2010 with the value of the efficiency of 0,905 and 0,975; and in the year 2011-2014 Sidoarjo Regency always efficient. Pasuruan efficient in 2007, then become inefisien on the year 2008-2010, after it is efficient back from the year 2011-2014. Kediri City from the same period last year 2007-2014 Research, reaching efficient only in 2012 and 2014. Mojokerto district from the same period last year 2007-2014 Research, reaching efficient only in 2010 and 2012. Bangkalan Regency from the same period last year 2007-2014 Research, reaching efficient only in 2013 and 2014. In Madiun district who achieve efficient only in the year 2014. Blitar district, Jember, and Situbondo, achieve efficient only in the year 2012. Malang Regency, Ngawi, and Pamekasan, achieve efficient only in the year 2010, after that become inefisien for expenditures in the education sector.

In general, it can be concluded that in 2007, there are 7 districts; namely Mojokerto city, Blitar city, Pasuruan, Sidoarjo, Malang, Ngawi and Pamekasan. In the year 2008 districts and cities that achieve efficient; there are 3 namely Mojokerto city, Blitar city, and Sidoarjo. In 2009 there are only 2 areas that achieve efficient, Mojokerto city and Blitar city. In 2010 regions that achieve efficient there are 3 districts, namely Mojokerto city, Blitar city, and Mojokerto. In 2011 there are 4 regions that achieve efficient, namely Mojokerto city, Blitar city, Pasuruan city, and Sidoarjo Regency. In 2012 there are 8 regions that achieve efficient, namely Mojokerto city, Sidoarjo, Pasuruan, Kediri city, Mojokerto, Blitar, Jember, and Situbondo. In 2013 there are 5 regions that achieve efficient, namely Mojokerto city, Blitar city, Pasuruan, Sidoarjo, and Bangkalan. In the year 2014 efficient areas there are 6 districts namely the City of Blitar, Pasuruan, Sidoarjo Regency, Kediri City District, Bangkalan Regency and Madiun.

\subsection{The efficiency of the Education Sector with the assumption of the VRS}

Variable Return to Scale (VRS) for all units that measured will produce changes on various output levels where each DMU considered will operate at the level of the scale of return vary. VRS Model assumes that each DMU does not operate at an optimal scale, where the ratio of the addition of the output and input is not always the same so that if there is an additional input as much as $\mathrm{n}$ times, output will not always increase as much as $\mathrm{n}$ times (constant return to scale), can even more (increasing return to scale) or less (decreasing return to scale) from time to times. In the VRS model there is also the assumption that the scale of production can affect the efficiency and productivity that everything. The technology is one of the factors that affect the VRS, indicate the possibility of the scale of production affect the efficiency. 
Table 5. The Change of Efficiency Scores in Several Regions across Years with VRS Assumptions

\begin{tabular}{|c|c|c|c|c|c|c|c|c|}
\hline Municipal & 2007 & 2008 & 2009 & 2010 & 2011 & 2012 & 2013 & 2014 \\
\hline Situbondo & 1.000 & 1.000 & 1.000 & 1.000 & 1.000 & 1.000 & 1.000 & 1.000 \\
\hline Pamekasan & 1.000 & 1.000 & 1.000 & 1.000 & 1.000 & 1.000 & 1.000 & 1.000 \\
\hline Sumenep & 1.000 & 1.000 & 1.000 & 1.000 & 1.000 & 1.000 & 1.000 & 1.000 \\
\hline Blitar city & 1.000 & 1.000 & 1.000 & 1.000 & 1.000 & 1.000 & 1.000 & 1.000 \\
\hline Kediri city & 1.000 & 1.000 & 1.000 & 1.000 & 1.000 & 1.000 & 1.000 & 1.000 \\
\hline Sidoarjo & 1.000 & 1.000 & 0.942 & 1.000 & 1.000 & 1.000 & 1.000 & 1.000 \\
\hline Lamongan & 1.000 & 0.906 & 0.875 & 1.000 & 1.000 & 1.000 & 1.000 & 1.000 \\
\hline Madiun & 1.000 & 1.000 & 1.000 & 0.643 & 1.000 & 0.977 & 1.000 & 1.000 \\
\hline Magetan & 1.000 & 1.000 & 1.000 & 0.516 & 1.000 & 1.000 & 1.000 & 0.844 \\
\hline Gresik & 1.000 & 0.835 & 0.765 & 1.000 & 1.000 & 1.000 & 1.000 & 0.814 \\
\hline Sampang & 1.000 & 1.000 & 1.000 & 0.847 & 0.657 & 0.980 & 1.000 & 1.000 \\
\hline Pasuruan & 1.000 & 0.991 & 0.958 & 0.993 & 1.000 & 1.000 & 1.000 & 1.000 \\
\hline Malang city & 1.000 & 1.000 & 1.000 & 0.662 & 1.000 & 0.835 & 1.000 & 0.772 \\
\hline Pacitan & 0.782 & 1.000 & 1.000 & 0.455 & 0.840 & 1.000 & 0.897 & 1.000 \\
\hline Mojokerto & 0.804 & 0.668 & 0.662 & 1.000 & 1.000 & 1.000 & 0.716 & 0.934 \\
\hline Malang & 1.000 & 1.000 & 1.000 & 0.620 & 0.660 & 0.850 & 0.665 & 0.701 \\
\hline Ngawi & 1.000 & 1.000 & 1.000 & 0.506 & 0.931 & 0.642 & 0.648 & 0.854 \\
\hline Ponorogo & 0.875 & 0.901 & 0.826 & 0.48 & 0.844 & 0.927 & 1.000 & 1.000 \\
\hline Trenggalek & 0.892 & 0.859 & 0.812 & 0.544 & 1.000 & 0.945 & 0.807 & 0.874 \\
\hline Blitar & 1.000 & 0.9 & 0.864 & 0.566 & 0.974 & 1.000 & 0.833 & 0.914 \\
\hline Kediri & 1.000 & 0.915 & 0.872 & 0.722 & 1.000 & 0.982 & 0.762 & 0.836 \\
\hline Jember & 0.925 & 0.757 & 0.767 & 0.681 & 0.852 & 1.000 & 0.829 & 0.802 \\
\hline Probolinggo city & 0.398 & 1.000 & 1.000 & 1.000 & 1.000 & 0.426 & 0.411 & 0.386 \\
\hline Nganjuk & 0.697 & 0.637 & 0.600 & 1.000 & 0.732 & 0.769 & 0.668 & 0.736 \\
\hline Probolinggo & 1.000 & 0.639 & 0.585 & 0.440 & 1.000 & 1.000 & 1.000 & 0.911 \\
\hline Bangkalan & 1.000 & 0.732 & 0.697 & 0.648 & 0.56 & 0.637 & 1.000 & 1.000 \\
\hline
\end{tabular}

Table 5 shows the efficient areas in the education sector the year 2007-2014. The results of the analysis DEA with VRS Assumption shows that regions consistent always efficient from the year 2007-2014 namely in Situbondo, Pamekasan, Sumenep Regency City of Blitar and Kediri City. In detail the efficient area on the education sector can be seen in Table 5 .

In the education sector, DEA analysis results with VRS Assumption shows that most inefisien area or that the value of the smallest efficiency is shown in Table 6 . The results of the analysis shows that most inefisien area in 2007, 2012-2014 namely Probolinggo city with the value of the efficiency of around 38-42\%, but in the year 2008-2011 Probolinggo city have reached the efficient. This is due to the fact that in the year 2007, 2012-2014 increased government spending in the education sector is not followed by an increase in the outputso that cause the Probolinggo city in years has become one of the most inefisien, while in the years 2008-2011 government spending the education sector is not how big but his output is greater than the year 2007, 2012-2014 and achieve efficient conditions.

Table 6. The Most Inefficient Regions with the Assumption of the VRS Analysis

\begin{tabular}{lllllllll}
\hline Municipal & 2007 & 2008 & 2009 & 2010 & 2011 & 2012 & 2013 & 2014 \\
\hline Probolinggo City & 0.398 & 1.000 & 1.000 & 1.000 & 1.000 & 0.426 & 0.411 & 0.386 \\
Nganjuk & 0.697 & 0.637 & 0.6 & 1.000 & 0.732 & 0.769 & 0.668 & 0.736 \\
Probolinggo & 1.000 & 0.639 & 0.585 & 0.44 & 1.000 & 1.000 & 1.000 & 0.911 \\
Bangkalan & 1.000 & 0.732 & 0.697 & 0.648 & 0.56 & 0.637 & 1.000 & 1.000 \\
\hline
\end{tabular}

In the year 2008 namely Nganjuk District with the value of the efficiency of $63.7 \%$, but on 2010 Nganjuk district has reached the efficient. This is due to the fact that in the year 2008 if compared with 2010 although in 2010 government spending in the education sector the larger, but also followed with the addition of the output more so on 2010 reach the efficient condition. 
In the year 2009 and 2010 namely Probolinggo District with the value of the efficiency of 44-58.5\%, but in 2007, 2011-2013 Probolinggo District has reached the efficient. This is due to the fact that in the year 2009 and 2010 output produced small, not as on the year 2011-2013 although input that issued the government is getting bigger, but the output produced is also the larger.

In 2011, Kabupaten Bangkalan with the value of the efficiency of 56\%, but in 2007, 2013-2014 Bangkalan Regency has reached the efficient. This is due to the fact that in 2011 government spending in Bangkalan Regency for the education sector is getting bigger, but the output produced thus further small, so that in that year Bangkalan Regency was the most inefisien.

Based on explanation can be seen that with the assumption of the CRS and VRS, the average value of the efficiency of regency/city of East Java Province to continue to decline in the year 2008-2010 then increase on the year 2011-2012 then declined again in 2013 and increased in the year 2014. The results of the analysis of DEA with CRS and VRS assumption shows different results. Assuming that the CRS number of areas that less efficient compared with the results of the analysis using the VRS assumption.

In the period 2007-2014 assuming CRS there is no consistent area always efficient for eight years and with VRS assumption there are five areas that always efficient for eight years namely in Situbondo, Pamekasan, Sumenep, Blitar City, and Kediri City. Assuming that the CRS, Probolinggo town for eight years in a row was the most inefficient. Assuming VRS, Probolinggo district is also the most efficient in 2007, 2012-2014; while in 2008 namely Nganjuk District, on the years 2009-2010 namely Probolinggo District, and on 2011 is Bangkalan Regency was the most inefficient.

This results in line with the results of research done by Merini (2013) about the efficiency of the Public Sector Government Pengeleuaran in Southeast Asia. Merini (2002) stated that the efficiency of government spending for the education sector in Indonesia number five after Cambodia, Philippines, Singapore and Brunei Darussalam with an average efficiency score $64,4 \%$. Yet the efficiency of government spending in the education sector is caused is still the education gap between rural and urban, between the West and East Indonesia, between groups of people with varied income, and as well as between the sexes. Other factors that became the cause of the problem is the shortage of teachers, especially in remote areas, teachers multi grade, around 13 percent of the education budget is used to pay salaries and teachers certification. The results of World Bank research shows that the question of procurement in relation to the increasing number of teachers to add new teachers will not improve learning results. At school level, no correlation between the addition of teachers and students in basic education level for both the eyes of language lessons or mathematics. The same thing also happened in education Expenditure per student in the district level (which is very depending on salaries and teachers certification) not correlates with the results of the national examination. (Merini, 2013).

There are still many areas in East Java is not efficient in allocating government spending in the education sector, so required special attention to the areas that have not been efficiently so that on the next period can achieve efficient conditions. The result shows that the district government/city of East Java Province not right in identifying the problem on the budgeting process and the allocation of government spending in the education sector. The government is still not optimal performance in identifying and analyzing problems in the public service in the education sector in both faculty, education facilities, education infrastructure and administration, so planning budgeting expenditure for the education sector is still less accurate. Finally, the realization of the expenses of the local government has not been able to achieve the quality and the quality of education which is expected so that there are still many areas in the district of the province of East Java that inefisien. It is expected that the government can be regrouping problems in the basic education sector so that it can be found a variety of improvement effort and done the budgeting process and the allocation of the right spending so that later expenditures are able to improve the quality of public education in each district of the province of East Java.

\subsection{The effectiveness of government spending on Education Sector}

Based on the results of the Hausman test results obtained the estimation of the panel data using the method of random effect (REM) lag 1 is more suitable in mengestimasi panel data. The results of the estimation of panel data with the lag brake method 1 is:

$$
\text { IP = 3,4982 + 0,8109PPPt-1 + 1,2340PPRTt-1 + 7,3950lnPDRBt-1 }
$$

Government spending for the education sector (PPP) did not show a significant influence of IP. Meanwhile, household spending for education (PPRT) and Regional GDP per capita (lnPDRB) have positive and significant impact on the index of Education (IP).

The result shows that the expenditure of the government for the education sector is still not influence the 
improvement of education index or in other words the government spending is still not effective for the improvement of the quality of human resources and the city district in East Java Province. These results strengthen the findings on the efficiency of government spending in the education sector. Government spending in the education sector in most of the district and the city of East Java Province is not efficient.

Ineffective government spending district education sector and the city in East Java Province period of 2007 2014 in line with the results of research done by Rajkumar and Swaroop (2007) about the effectiveness of government spending by using the institutional quality variable/institutional. The results of the study showed that the public expenditure does not provide a significant impact on the improvement of outcome that is expected to the human development index. Empirically, the difference in the effectiveness of public spending can be explained by the differences in the governance as measured by the level of corruption and the quality of the bureaucracy. The same result was also obtained in research done by Craigwell, Lowe, and Bynoe (2012). The results of the study showed that health spending has a significant positive influence to the improvement of health status. Meanwhile, education spending does not have a good influence on the number of primary school participation and medium.

Based on the three research results above can be taken a conclusion that the effectiveness of government spending one depending on governance and the use of the budget. In the case of the district and the city of the province of East Java using the method of random effect where the assumption that used all areas are considered the same characteristics, governance and budget policy cause the expenditure of the government for the education sector that did not affect the index of education. This happened because the characteristic, governance and budget policy each district in fact different from that to which each region has a different budget policy in accordance with the interests and the condition of the respective areas.

Education index in this research is influenced by the variables household spending for education and Regional GDP per capita or in other words both variables is effective in improving education index. This can be explained that the cost of education issued by household contribute directly to the improvement of education family members. Household spending in the education sector illustrates the greatness of non food expenditure issued by household to the cost of education, which includes money registration, the cost of purchasing books, donations parents, extracurricular activities, courses, and others. This spending can be said to provide the influence directly against a number of literacy and mean years schooling as indicator of education.

The results of this research is also in line with the statement delivered by Marieta (2010) that the level of efficiency of the expenditure of the government is very concerned with the effectiveness of the expenditure of the government itself. The efficiency will not be achieved without the effectiveness and effectiveness is a prerequisite (necessary condition) to reach efficiency. This means that the efficiency of government spending in the education sector is very dependent on the effectiveness of the implementation of programs in the education sector.

\section{References}

. (2008). Microeconomic Theory: Basic Priciples and Extensions (10th ed.). USA: Thomson South - Western.

Afonso Antonio and Miguel St. Aubyn. (2005). Non-Parametric Approaches to Education and Health Fouling in OECD countries. The Journal of Applied Economics, 3(2), 227-246. Retrieved from http://www.ucema.edu.ar/publicaciones/download/volume8/afonso.pdf

Akhmad \& Bustang. (2013). The effectiveness of fiscal policy toward Economic Area District and Provincial City (the Case Study of South Sulawesi Province). The Bappenas library 02/year XIX. Edition

Andersen, P., \& NC. Petersen runs. (1993). A Procedure for Ranking Efficient Units in Data Envelopment Analysis. Management Science, 39(10), 1261-1264.

Asghar, N., Hussain, Z., \& Ur Rehman, H. (2012). The Impact of Government Spending on Poverty Reduction: Evidence from Pakistan 1972 to 2008. African Journal of Business Management, 6(3), 845-853. https://doi.org/10.5897/AJBM11.922

Assifie, B. (2004). Analysis of the performance of the organization with the approach of System Dynamic: Study cases on Taxation using the Modification Perspective Balanced Scorecard. The thesis, not published, post-Graduate Program Administration Science Department FISIP UI.

Bagdigen, M., \& Centitas, H. (2003). Causality between Public Expenditure and Economic Growth: The Turkish Case. The Journal of Economic and Social Research, 6(1), 53-72. Retrieved from https://mpra.ub.uni-muenchen.de/8576/1/MPRA_paper_8576.pdf 
Baltagi, B. H. (2002). Econometric Analysis of the Panel Data. Third Edition. England: John Wiley \& Sons, Ltd.

Becker, S. G. (1993). Human Capital: A range and Empirical Analysis with Special Reference to Education (3rd ed.). The University of Chicago Press: London.

Bogetoft, P., \& Hougaard, J. L. (2000). Super Fouling Evaluations Based on Potential Slack. European Journal of Operation Research, 152(1), 14.

Coelli, T. J., Rao", D. S. P., O'Donnell, C. J., \& Battese, G. E. (2005). An Introduction to fouling and Productivity Analysis: Second Edition. The United States of America: Springer.

Cooper, W. W., Seiford, L. M., \& Tone, K. (2007). Data Envelopment Analysis. USA: Springer.

Craigwell, R., Bynoe, D., \& Lowe, S. (2012). The Effectiveness (of Government Expenditure on Education and Health Care in the Carribean. The International Journal of Development Issues, 11, 4-18. https://doi.org/10.1108/14468951211213831

Danu, A. \& Zuhdi, U, (2013). The Government Expenditure Fouling toward the Human Development. Procedia Economics and Finance, 5, pp.615-622. https://doi.org/10.1016/S2212-5671(13)00072-5

Emanuele Baldacci, Guin Siu, Maria Teresa., \& de Mello, Luiz. (2003). More on The Effectiveness (of Public Spending on Health Care and Education: A Covariance Structure Model. The Journal of International Development, 15, 709-725. Retrieved from https://www.imf.org/external/pubs/ft/wp/2002/wp0290.pdf

Fritzen, S. A., \& Patric W. O. Lim. (2006). Problems and prospects of Decentralization in Developing Countries. Encyclopedia of Public Administration and Public Policy.

Gujarati, D., \& Porter, D. C. (2009). Basic Econometrics. New York. McGraw Hill.

Gupta, S., \& Verhoeven, M. (1999). The Fouling of Government Expenditure Experiences from Africa. The Journal of Policy Modeling, 23, 433-467. https://doi.org/10.1016/S0161-8938(00)00036-3

Gupta, S., Verhoeven, M., Tiongson, \& Erwin, R. (2002). The Effectiveness (of Government Spending on Education and Health Care in developing and Transition economies. European Journal of Political Economy, 18, 717-737. https://doi.org/10.1016/S0176-2680(02)00116-7

Haksever, C., Barry, R., Roberta, S., \& Murdick, R. G. (2000). Service Management and Operations (2nd ed.). NJ: Prentice Hall.

Halim, A. (2008). Regional financial accounting. Jakarta: Salemba four.

Hamid, H. S. (2013). Decentralization and Public Service Delivery in Indonesia: The Case of Road Infrastructure. Thesis. Hungary Central European University.

Hauner, D., \& Koybe, T. (2010). Fouling determinant of Government. World Development, 38(11), 1527-1542.

Henry, O., \& Olekalns, N. (2010). Peacock and Wiseman's Displacement Hyphothesis: tackles the New Long Run Evidence for the UK. Applied Economics, 42(11), 1455-1460.

Insukindro, N., Makhfatih, A., \& Ciptono, S. M. (2000). The final report: measurements relative efficiency service branch offices pawning. Yogyakarta: Management Research and Development (PPM) Economic Faculty of the University of Gadjah Mada University.

Jafarov, E., \& Gunnarson, V. (2008). Government Spending on Health Care and Education in Croatia: Fouling and Reform Options. The IMF Working Paper. WP/08/136. Retrieved from https://www.imf.org/external/pubs/cat/longres.aspx?sk=21978.0

Kwon \& Dae-Bong. (2009). Human Capital and Its chaired the. The 3rd OECD World Forum on Statistics, Knowledge and Policy Charting Progress, Building Visions, Improving Life. Busan: 1-15.

Litvack, J., \& Jessica, S. (1999). Decentralization Briefing Notes. WBI Working Papers, World Bank Institute.

Loehr, W., \& Manasan, M. (1999). Fiscal Decentralization and Economic Fouling: Chaired and evaluation. Consulting Assistance on Economic Reform II Discussions Papers. USA: Harvard Institute for International Development.

Lovell, C. A. K. (1993). Production Frontiers and another obvious lesson Fouling in Fried HO and SS Schimdt: "the chaired of another obvious lesson Fouling: Techniques and Application. The United of Kingdom: OUP.

Maitra, B., \& Mukhopadhyay, C. K. (2012). Public Spending on Education, Health Care and Economic Growth in selected countries of Asia and the Pacific. Asia-Pacific Development Journal, 2(19), 19-48. Retrieved from https://papers.ssrn.com/sol3/papers.cfm?abstract_id=2222668 
Marieta, D., Opreana, A., \& Cristescu, M. P. (2010). Fouling, Effectiveness and performance of the Public Sector. Romanian Journal of Economic Forecasting, (4), 132-147. http://www.ipe.ro/rjef/rjef4_10/rjef4_10_10.pdf

Merini, D. (2013). Analysis of the efficiency of the Public Sector government spending in the Southeast Asian region: Application Data Envelopment Analysis. Retrieved December 10, 2016, from http://portalgaruda.org

Nurhemi, \& Thunder Suryani, R. (2015). The impact of the regional financial autonomy to economic growth in Indonesia. Bulletin of the monetary economy and banking, 2(18), 183-206.

Oates, W. E. (1993). Fiscal Decentralization and Economic Development. National Tax Journal, 237 - 243.

Petrov, N. D. (2013). Estimation of Effectiveness (of the Bank of Russia Interest Rate Policy, Thesis. National Research University. Moscow.

Pindyck, R. S. \& Rubinfield, D. L. (2007). Mikroekonomi: Sixth Edition. Jakarta: PT. The Index.

Prasetyo, A. D., \& Zuhdi, A. U. I. (2013). The Government Expenditure Fouling Toward Human Development. Procedia Economics and Finance, (5), 615-622.

Rania, G., \& Stewart, F. (1994). Decentralisation in Indonesia. Bulletin of Indonesian Economic Studies, 30(3), 41-72.

Rayp, G., \& van de Sijpe, N. (2007). Measuring and Explaining Government Fouling in developing countries. The Journal of Development Studies, 43(2), 360-381. Retrieved from https://www.econstor.eu/bitstream/10419/19823/1/Van_der_Sijpe.pdf

Rosen, H. S. (1999). Public Finance (5th ed.). Boston Burr Ridge, McGraw-Hill.

Rosenman, R., \& Friesner, D. (2004). Scope and scale installation design efficiencies in Physician Practices. Health Economics, 13(11), 91-116.

Samuelson, P. A., \& Nordhaus, W. D. (2001). Macroeconomics (17th ed.). The Mc.Graw-Hill Higher Education.

Snyder, C., \& Nicholson, W. (2007). Theory and Application of Intermediate Microeconomics (10th ed.). USA: Thomson South - Western.

Stephen, O., \& Oluranti, O. I. (2011). Government expenditure on Human Capital Development: Implication for Economic Growth in Nigeria. The Journal of Sustainable Development, 4(3), 72-80.

Suescún, R. (2007). The Role of Fiscal Policy in Human Development and growth. LAC Regional Study, Latin America and the Caribbean Region. The World Bank.

Talluri, S. (2000). Data Envelopment Analysis: Model and Extensions. Decission Line, 31(3), 8-11.

The Directorate General of Finance and balance. (2012). The budget and the realization of the Regional Financial Year 2007 -2013. Jakarta, the Ministry of Finance of The Republic of Indonesia.

The State Ministry of Administrative Reform. (2008). Instructions for preparation of Key Performance Indicators. Jakarta: National bureaucracy reform Team.

The United Nation Development Program (UNDP). (2005). Decentralization and District Development: Pra \& Multi-Sectoral Framework for Decentralized Policies and Local Development Strategies Address to the Millennium Development Goals. Working Paper UNDP 3. The UNDP Mozambique

Verhoeven, M., Gunnarsson, V., \& Carcillo, S. (2007). Education and Health in G7 Countries: Achieving Better Outcomes with Less Spending. The IMF Working Paper. 07/263, (Washington: The International Monetary Fund)

Wijeweera, A., \& tons of the line. (2009). Wagner's Law and Social Welfare: The Case of the Kingdom of Saudi Arabia. Applied Econometrics and International Development, 9(2).

Wooldridge, J. M. (2012). Introductory Econometrics A Modern Approach (5th ed.). USA: Cengage Learning.

Zhu, J. (2001). Super Fouling and DEA Sensitivity Analysis. EJOR, 129(2), 443-455.

\section{Copyrights}

Copyright for this article is retained by the author(s), with first publication rights granted to the journal.

This is an open-access article distributed under the terms and conditions of the Creative Commons Attribution license (http://creativecommons.org/licenses/by/4.0/). 